\title{
Perceptions and Challenges Regarding Cyberbullying during the Covid-19 Pandemic
}

\author{
Cristina Ispas, Ana-Maria Eugenia Ispas
}




\title{
Perceptions and Challenges Regarding Cyberbullying during the Covid-19 Pandemic
}

\author{
Cristina Ispas ${ }^{a^{*},}$, Ana-Maria Eugenia Ispas ${ }^{b}$ \\ ${ }^{a}$ Educational Sciences Department, UBB University Studies Center from Reșița, T. Vuia Square, No.1-4, Reșița, 320 085, Romania \\ ${ }^{b}$ Department of Psychology, UBB University Studies Center from Reșița, T. Vuia Square, No.1-4, Reșița, 320 085, Romania
}

*Corresponding author: cristina.ispas@ubbcluj.ro

\section{Abstract}

\section{Keywords:}

cyberbullying; Covid-19; cyberaggressor; cyber-victim; cyberwitness; internet.
The increased use of the Internet and digital communication platforms has facilitated the emergence and development of the phenomenon known in the literature as cyberbullying. This research aims to examine the perception of the interviewees about the phenomenon of cyberbullying in the period marked by the Covid 19 pandemic. In this research the method of sociological survey based on questionnaire was used. The research was attended by 541 people, mostly young people ( $83.5 \%$ of the interviewees are under 30 years old). The findings showed that the interviewees know to a large extent the phenomenon of cyberbullying; respondents believe that this phenomenon spread during the Covid 19 pandemic; half of those surveyed witnessed the phenomenon of cyberbullying, while $44.7 \%$ say they know people who have been victims of cyberbullying. The present study analyzes the way in which the interviewees position themselves in relation to different acts specific to cyberbullying. The study also highlights the opinions of the interviewees on effective action strategies to combat cyberbullying.

Die verstärkte Nutzung des Internets und digitaler Kommunikationsplattformen hat die Entstehung und Entwicklung des in der Literatur als Cybermobbing bekannten Phänomens erleichtert. Ziel der Untersuchung ist es, die Wahrnehmung der Befragten zum Phänomen Cybermobbing in der Zeit der Covid-19-Pandemie zu untersuchen. In dieser Untersuchung wurde die Methode der soziologischen Erhebung auf der Grundlage von Fragebogen verwendet. An der Studie nahmen 541 Personen teil, überwiegend junge Leute $(83,5 \%$ der Befragten sind unter 30 Jahre alt). Die Ergebnisse dieser Recherche zeigten, dass die Befragten das Phänomen Cybermobbing weitgehend kennen; die Befragten glauben, dass sich dieses Phänomen während der Covid-19Pandemie ausgebreitet hat; die Hälfte der Befragten war Zeuge des Phänomens Cybermobbing, während 44,7\% angeben, Menschen zu kennen, die Opfer von Cybermobbing geworden sind. Die vorliegende Studie analysiert, wie sich die Befragten vor verschiedenen Cybermobbing-spezifischen Taten positionieren. Die Studie beleuchtet auch die Meinung der Befragten zu wirksamen Handlungsstrategien zur Bekämpfung von Cybermobbing.

\section{Introduction}

The exponential growth of virtual communications in the last decade has drastically changed the way individuals interact, often changing learning strategies, entertainment options. (Sonone et al., 2020). The rapid spread of social networks on the Internet, as well as the use of electronic communication tools such as email, websites, instant messaging, webcams, chat rooms, social networking sites, blogs and text messages (Hinduja \& Patchin, 2010; Palfrey \& Gasser, 2008) facilitated the exchange of information in various forms (text messages, graphics, audio-video, etc.) at any time of day or night, in real time.

The specific context generated by the Covid 19 pandemic has led to an increase in the use of communication technologies via the Internet in almost all areas of activity. The need for physical distance from others, as a measure to prevent infection with the Sars Cov 2 virus, has led to a rapid increase in the number of people who frequently use and own digital media.

\section{Theoretical foundation}

According to various dictionaries, the concept of cyberbullying refers to:

- "the use of electronic communication to bully a person, typically by sending messages of an intimidating or threatening nature." (Oxford English Dictionary) 
- "the activity of using messages on social media, emails, text messages, etc. to frighten or upset somebody" (Oxford Advanced Learner's Dictionary)

- "the activity of using the internet to harm or frighten another person, especially by sending them unpleasant messages" (Cambridge Dictionary)

- "the act of harassing someone online by sending or posting mean messages, usually anonymously." (Dictionary.com)

Among the most credible definitions of cyberbullying are those of Smith, Mahdavi, Carvalho, Fisher, Russell and Tippett (2008), who define cyberbullying as an aggressive act performed through the use of electronic means of communication, individual or group, repetitive and durable over time against a victim who cannot easily defend himself. Patchin and Hinduja (2006) state that cyberbullying causes intentional rather than episodic damage caused by the use of electronic means, "cyberbullies have some perceived or actual power over their victims" (Patchin \& Hinduja, 2006, p.152).

Cyberbullying is a form of bullying that takes place online. Thus, cyberbullying presents a series of elements common to the bullying phenomenon, such as intentionality, repetitiveness / persistence, power asymmetry. Between the two phenomena, bullying and cyberbullying, there are aspects that differentiate and nuance their specificity. If in bullying the aggressor's power was usually of a physical or social nature (competence or popularity), in cyberbullying the power can take the form of competence in the use of technology (digital competences), doubled by the possibility of access to technology and internet. "That is, youth who are able to navigate the electronic world and utilize technology in a way that allows them to harass others are in a position of power relative to a victim." (Patchin \& Hinduja, 2006, p.152).

Cyberbullying tends to be more severe than bullying. Unlike bullying, victims of cyberbullying cannot be physically removed, as electronic devices continuously notify and download content from social networks or various sites. (Tanrikulu, Kinay \& Aricak, 2015). At the same time, cyberbullies feel less inhibited in communicating with potential victims through electronic devices (Suler, 2004).

Cyberbullying takes different forms, being difficult to capture the real dimension of this phenomenon, given the fact that not all acts of cyberbullying are reported, and accurate statistics on this phenomenon are difficult to achieve.

\section{Research methodology}

The research was conducted using the method of sociological survey, based on a questionnaire. All persons involved in the research completed the online questionnaire. The research tool (questionnaire) included 12 items, of which 9 items of content and 3 items of identification.

\subsection{The aim and the objectives of the research}

The aim of the research was to identify the perception of the interviewees regarding the phenomenon of cyberbullying in the period marked by the Covid 19 pandemic. The goal was achieved through the following objectives:

- SO1: knowing the degree of familiarity of respondents with the phenomenon of cyberbullying

- SO2: identifying the perception of the evolution of the phenomenon of cyberbullying among young people during the Covid19 pandemic;

- SO3: identification of the mode of participation (as a witness, aggressor, victim) or nonparticipation of respondents in various forms of cyberbullying;

- SO4: highlighting respondents' perception of the main reasons for a person to engage in specific actions of cyberbullying

- SO5: specifying possible strategies for action in cyberbullying

\subsection{Research period}

The research was conducted between March 2021 - June 2021.

\subsection{Investigated population - sample structure}

The research involved 541 people from western Romania (Caraş-Severin and Timiș counties) who have the following characteristics depending on:

- Age

- $\quad$ under 14 years - 7 persons (1.3\%)

- between 15 years-20 years - 283 persons (52.3\%)

- between 21 years-25 years - 132 persons (24.4\%)

- between 26 years-30 years - 30 persons (5.5\%)

- over 30 years - 89 people $(16.5 \%)$

- Gender

- $\quad$ Male - 161 persons (29.8\%) 
- Female - 380 persons $(70.2 \%)$

- Area of residence

- Urban area - 341 persons (63\%)

- Rural area - 200 persons (37)

\section{- Social status}

- $\quad$ student in high school - 7 persons (1.3\%)

- $\quad$ student in high school - 234 persons (43.3\%)

- $\quad$ student (bachelor, master) - 216 persons (39.9\%)

- employee - 70 persons $(12.9 \%)$

- unemployed, homemaker - 9 persons (1.7\%)

- Others: - 5 persons $(0.9 \%)$

\section{Results}

In the presentation and interpretation of the data we chose to structure them according to the research objectives:

- SO1: knowing the degree of familiarity of the respondents with the phenomenon of cyberbullying

To ensure that all respondents understand the term cyberbullying, a short description of this concept was introduced at the beginning of the questionnaire: "cyberbullying is a form of bullying aggression using digital technologies. It takes place on various sites that allow interaction through messages, on social networks, on message exchange platforms, game platforms and on mobile phones. Cyberbullying refers to intentional behavior, repeated in order to denigrate, scare, anger or humiliate those targeted.

Figure 1. The degree of knowledge of the phenomenon of cyberbullying by research participants

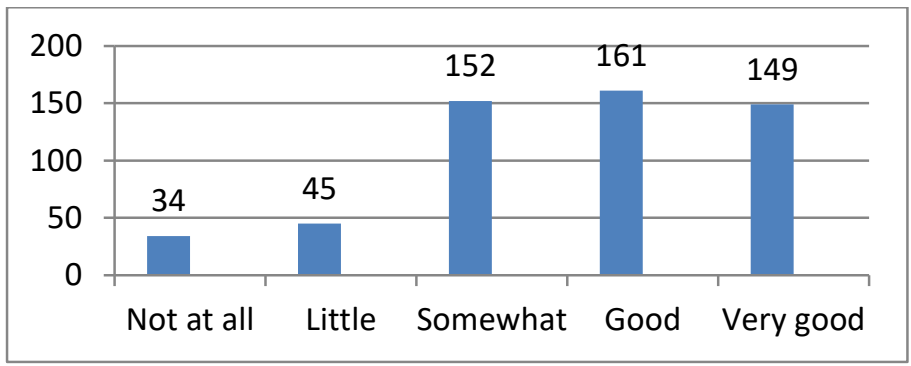

The survey of the respondents regarding the degree of knowledge of the cyberbullying phenomenon was done by using a scale from 1 to 5 , where 1 meant Not at all, and 5 -very well. The results obtained are shown in the graph below. It is observed that a relatively small number of respondents (34 people, 6.3\%) state that they do not know the phenomenon of cyberbullying, while at the opposite pole, 149 people $(27.5 \%)$ consider that they know it very well.

Knowledge of a phenomenon such as cyberbullying indicates the extent to which respondents are informed about the existence of this phenomenon, the attention paid to understand its manifestation $\&$ its consequences. In our opinion, a high degree of knowledge of the phenomenon of cyberbullying implies the approach to its specificity, by assuming roles such as: cyber-aggressor, cybervictim, cyber-witness. The data obtained from the following items confirm this hypothesis of ours.

- O2: identifying the perception of the evolution of the phenomenon of cyberbullying among young people during the pandemic with Covid 19;

"The COVID-19 pandemic radically changed the context for bullying dynamics." (Bacher-Hicks et al., 2021).

The pre-pandemic literature with COVID 19 has reported the link between the increasing frequency of Internet use and the significant increase in cases of cyberbullying and cyber victimization among young people. (Kowalski, Giumetti, Schroeder, Lattanner 2014, Kowalski, Limber, McCord, 2019, Calvete et al., 2010).

Since March 2020, under the conditions of the Covid 19 pandemic, the excessive use of the Internet as a means of distance communication has allowed those with a tendency towards aggression to look for new ways of expression, in the shadow of the anonymity generously offered by the Internet. To date, few studies have looked at how reducing personal interactions and increasing communication through virtual technologies has impacted the phenomenon of bullying and cyberbullying. (Bacher-Hicks et al., 2021)

Jain et al. (2020) found that online behaviors associated with an increased risk of cyberbullying increased during the pandemic. Studies that analyze online searches about the phenomenon of cyberbullying using search engines, note that "in spring 2020, when schools shifted to remote learning due to the pandemic, search for school bullying and cyberbullying both dropped about $30-40 \%$. That drop is sustained through the subsequent 2020-21 school year, particularly in areas where more schools remained fully remote. (Bacher-Hicks et al., 2021) 
According to the participants in the research, the evolution of the phenomenon of cyberbullying in the last year (2020-2021) among young people:

- there was a significant reduction in the number of cases (24 persons, $4.4 \%$ )

- there was a slight decrease (26 persons, $4.8 \%$ )

- it remained at approximately the same level (63 persons, 11, 6\%)

- registered a slight increase (119 persons, 22\%)

- registered a significant increase (201 persons, $37.2 \%)$

- do not know (108 persons, 20\%).

As can be seen from the data obtained most respondents consider that the phenomenon of cyberbullying is on the rise, which can be explained by the COVID 19 pandemic, when internet communication has grown exponentially, providing people with aggressive tendencies with the perfect environment to implement their ideas to intentionally hurt and repeated other $\mathrm{p}$ people.

- SO3: identification of the mode of participation (as a witness, aggressor, victim) or nonparticipation of respondents in various forms of cyberbullying;

Cyberbullying phenomenon involving three roles: aggressor (cyberbully), victims and witnesses (witnesses - part of the problem or witnesses - part of the solution). (Willard, 2007). According to UNICEF, "anyone can become a victim of cyberbullying" (https: //

www.unicef.org/romania/ro/pove\%C8\%99ti/cyberbu llying-ce-este-\%C8\%99i-cum-\%C3\%AEi-punemcap\%C4\%83t).

Research shows that "numerous adolescents repeatedly fall victim to bullying (cyberbullying)" (Katzer et al, 2009, p.32). The long-term consequences for victims can be very severe, including a higher likelihood of depression, anxiety, and drug abuse (Kowalski et al., 2014)

When asked if they know someone who was a victim of cyberbullying, $44.7 \%$ of the respondents ( 242 people) answered affirmatively, while $41.6 \%$ (225 people) answered negatively to this item, and $13.7 \%$ (74 people) have avoided giving an affirmative or a negative answer.
Knowing a person/victim of cyberbullying makes the phenomenon of cyberbullying not something abstract, but something related to the respondent through the person he/she knows. People who answered "yes" to this item found themselves in one of the situations: either they were the aggressors, or witnesses (direct or indirect - by telling the situation of cyberbullying by another person), or victims. Also, even among the people participating in the investigation, there is a good chance that some of the people who avoid giving an affirmative or negative answer are in the position of victims and / or aggressors and due to feelings of shame, embarrassment, guilt, anger, non-acceptance, etc. prefer neutral answers such as "I don't know / don't answer".

Figure 2. Results regarding the knowledge or not of a cyberbullying victim

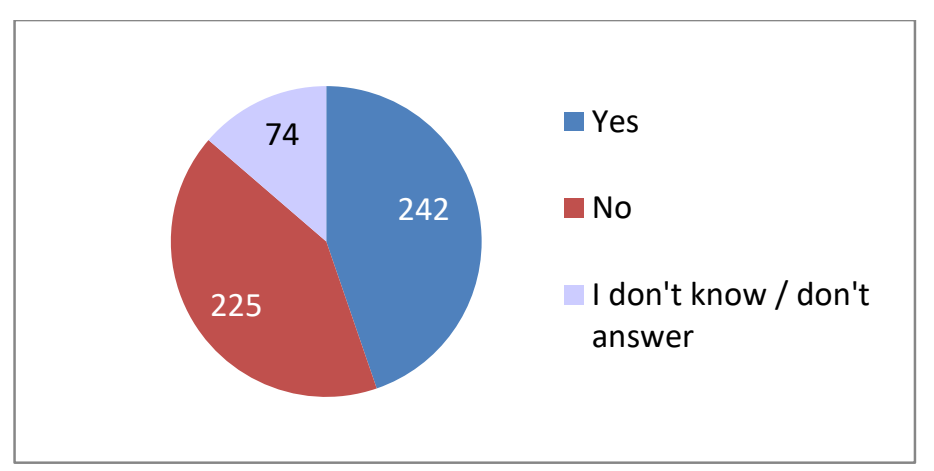

Table 1. Results regarding the knowledge or not of a person victim of cyberbullying

\begin{tabular}{lll}
\hline Answers & Nr. of people & $\%$ \\
\hline Yes & 242 & $44,7 \%$ \\
No & 225 & $41,6 \%$ \\
Don't know/ Don't answer & 74 & $13,7 \%$ \\
\hline
\end{tabular}

As we mentioned, the concept of "cyberbullying" (Ybarra \& Mitchell, 2007) refers to the actions of posting comments, information, images, audio-video clips, etc. online that repeatedly and intentionally seek to offend, shame, frighten or denigrate someone by accessing that content by a wide audience. Often someone can unwittingly end up witnessing episodes of cyberbullying. In the present research we were interested to find out to what extent the research participants ever witnessed an episode of cyberbullying and how they would act if they found themselves in such a situation.

The responses received to the item if they have ever witnessed an episode of cyberbullying seem balanced, in the sense that almost half of the respondents say they were not witnesses (this does not 
exclude the possibility that among those who say they were not witnesses there are people who participated in cyberbullying, but as cyber-aggressors or cybervictims; obviously, among the respondents are also people who did not take part directly in cyberbullying either as witnesses or as victims or aggressors), while the other half also specifies the frequency with which the episodes of cyberbullying in which they took part as witnesses took place (most people took part only once or twice).

Figure 3. Results on the number of people who witnessed cyberbullying

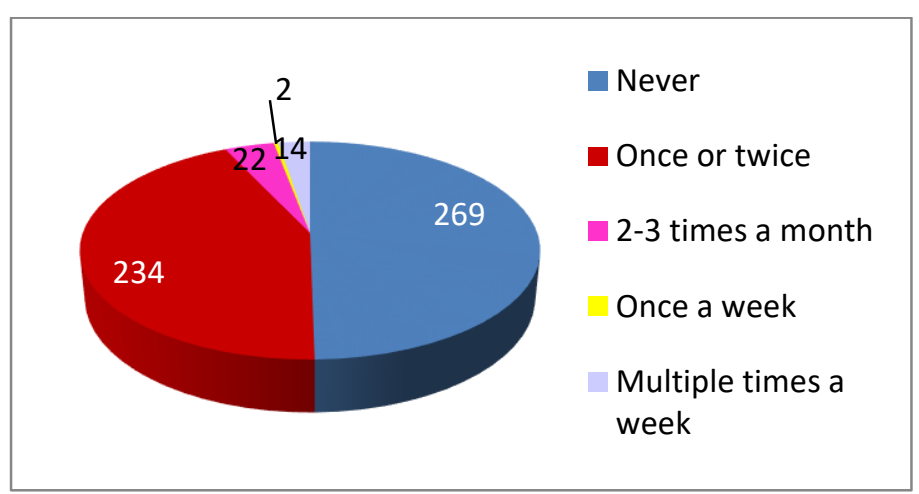

Table 2: Results on the number of people who witnessed cyberbullying

\begin{tabular}{lll}
\hline Answers & Nr. of people & $\%$ \\
\hline Never & 269 & $49,7 \%$ \\
Once or twice & 234 & $43,3 \%$ \\
$2-3$ times a month & 22 & $4,1 \%$ \\
Once a week & 2 & $0,4 \%$ \\
Multiple times a week & 14 & $2,6 \%$ \\
\hline
\end{tabular}

In order to identify the relationship that the respondents have with the phenomenon of cyberbullying, they were asked to specify the frequency (which varies from Never or Only once or twice, reaching up to 2-3 times a month or Once a week or From several times a week) faced with certain situations (presented in the left column of the table below) in the sphere of the phenomenon of cyberbullying. The results obtained are presented in Table 3.

Analyzing carefully the table below we can see to what extent the research participants were victims (the first 10 statements aim at the role of victim), aggressors (the next eight statements present situations characteristic of cyberbullies) the answers obtained from the respondents indicate the variant Never or Only once or twice which shows that in their case we cannot talk about cyberbullying but rather isolated incidents. Those who have faced these situations several times a month or even a week have a high risk of being directly affected by cyberbullying, respectively being a victim and / or aggressor. Several studies have shown that students are often not exclusively classifiable as aggressors or victims (Austin \& Joseph, 1996; Espelage \& Swearer, 2003; Veenstra et al., 2005) and that these roles often intertwine, alternate.

Receiving silent phone calls is found 2-3 times a month for 66 people, and much more often, respectively once a week for 21 people and several times a week for 8 people. Ignoring or being excluded from online groups several times a week happens to 10 people who participated in the research, while 9 people say that they receive several times a week, threats and insults by text message, on the Internet through websites, web pages, chat rooms, blogs, instant messaging (MSN, Facebook, Twitter, Myspace ...), by email, etc.

As aggressive online behaviors are concerned, far fewer participants state that they perform those actions repeatedly, 2-3 times a month, once a week or several times a week.

Table 3. Results on the frequency of respondents' confrontation with situations in the field of cyberbullying

\begin{tabular}{|c|c|c|c|c|c|}
\hline Answer variants & Never & $\begin{array}{l}\text { Only once } \\
\text { or twice }\end{array}$ & $\begin{array}{l}2-3 \text { times } \\
\text { a month }\end{array}$ & $\begin{array}{l}\text { Once a } \\
\text { week }\end{array}$ & $\begin{array}{l}\text { Several } \\
\text { times a week }\end{array}$ \\
\hline $\begin{array}{l}\text { I received threats and insults via text message, via websites, chat rooms, } \\
\text { blogs, instant messaging (MSN, Facebook, Twitter, Myspace ...), by } \\
\text { email etc }\end{array}$ & 319 & 180 & 25 & 8 & 9 \\
\hline $\begin{array}{l}\text { I received videos / photos / images with aggression or violence with me or } \\
\text { other acquaintances }\end{array}$ & 438 & 80 & 19 & 4 & 0 \\
\hline $\begin{array}{l}\text { I received videos / photos / images of embarrassing or intimate situations } \\
\text { with me or acquaintances }\end{array}$ & 410 & 100 & 25 & 6 & 0 \\
\hline I received silent phone calls (the caller does not speak) & 209 & 237 & 66 & 21 & 8 \\
\hline
\end{tabular}


I found out that someone stole personal information or material about me (e.g. pictures, audio-video recordings etc ...) and then used it to slander

me

I found out that someone shared personal and private material about me in order to have fun at my expense

I was deliberately ignored in groups online (chats, forums, Whatsapp groups, Facebook ...)

I was excluded or left out of online groups (chats, forums, Whatsapp groups, Facebook ...)

I learned that someone had hacked and used my password and account. under a false identity (e-mail, Facebook ...)

I found out that someone used my identification data (name, images, etc.) to create a false internet account

I sent threats and insults by SMS, on the Internet through websites, chat rooms, blogs, instant messaging (MSN, Facebook, Twitter, Myspace ...), by email etc

I shared videos / photos / images with aggression or violence via mobile phone, Internet (emails, websites, YouTube, Facebook, WhatsApp etc.)

I shared videos / photos / images with embarrassing or intimate situations of other people

I made hidden phone calls when I wanted to stress / insult / threaten someone

I manipulated personal information or materials about certain people (e.g.: pictures, audio-video recordings, etc ...) and I distributed them to laugh at or hurt those people

I have deliberately excluded or left out of online groups (chats, forums, WhatsApp groups, Facebook ...) certain people

I used fake Internet account (s) to harass others online

I contributed to the spread of gossip on the Internet
456

70

11

3

1

433

367

374

431

437

469

501

503

472

507

463

451
88

121

121

98

94

56

32

28

54

24

64

22

79
$69.9 \%$ ), are not aware of the consequences of their actions (301 persons, respectively 55.6\%); try to assert themselves in their group of friends (266 people, respectively 49.2\%), are insecure, emotionally unstable (252 people, respectively 46.6\%), education received in the family (237 people, respectively $43.8 \%$ ), envy (235 people, respectively 43.4\%). of the main reasons for a person to engage in cyberbullying-specific actions

For the item that regarded "the main reasons why someone commits cyberbullying" the following results were obtained in Graph 4: they want to have fun at the expense of others (378 people, respectively

Figure 4. Findings on the main reasons why someone commits cyberbullying

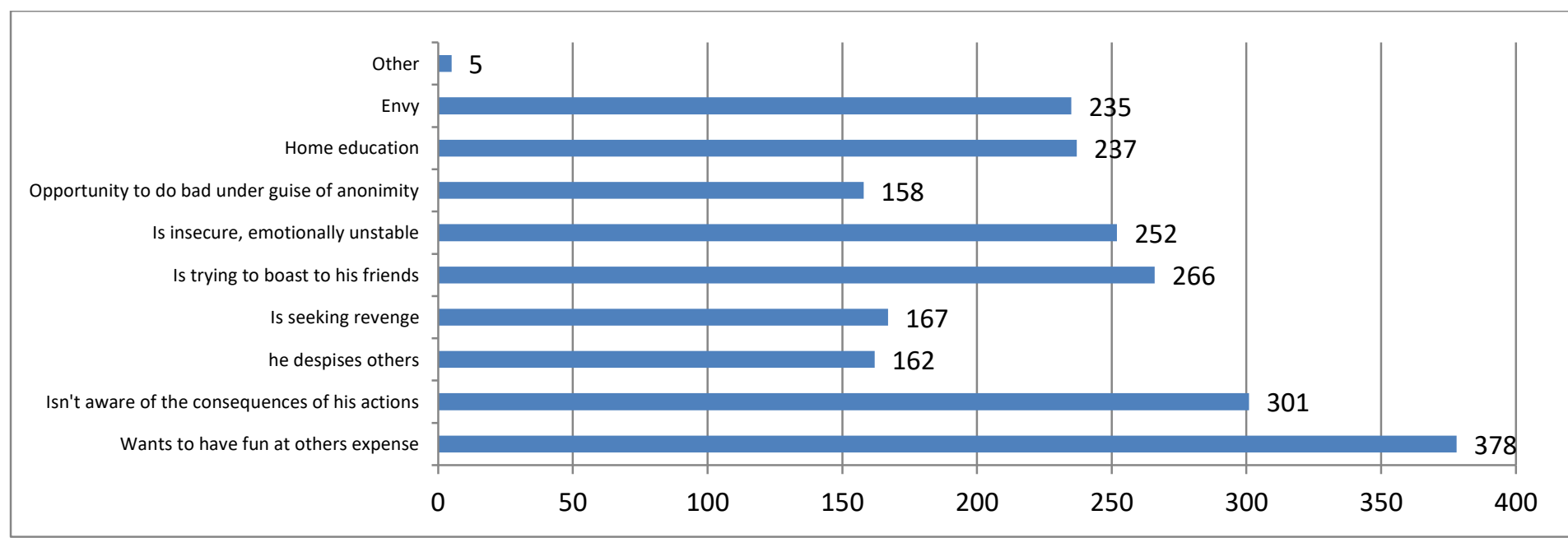


- SO5: specification of possible action strategies in cyberbullying situations.

The family has a particularly important role in preventing and combating the phenomenon of cyberbullying, a fact confirmed by the literature (Hinduja \& Patchin, 2014, 2020, 2021, Cortés-Pascual et al., 2020, Bonil-Nissim \& Sasson, 2018; IbáñezCubillas, Díaz-Martín \& Pérez-Torregrosa, 2017).

One of the most important roles of the school, of teachers, and the entire academic community in cyberbullying is to educate the community on the responsible use of digital communication devices, to convey that any form of cyberbullying is wrong and therefore unacceptable (Hinduja \& Patchin, 2021).

According to the respondents, "a person who is a victim of cyberbullying" should: ask for help from the family (360 people, $66.5 \%$ ) or go to the police / justice (299 people, $55.3 \%$ ) to not respond to the challenges from the aggressors (260 people, $48.1 \%$ ), to block the aggressor online (256 people, $47.3 \%$ ), to use the services of a psychologist / psychotherapist (211 people, 39\%), to ask help from their friends (193 people, $35.7 \%$ ), to talk to a teacher (162 people, $29.9 \%$ ) (see table 4).

Table 4. Results on possible cyberbullying action strategies

\begin{tabular}{lll}
\hline Answer variants & $\begin{array}{l}\text { Nr. of } \\
\text { people }\end{array}$ & $\%$ \\
\hline To ignore the situation & 115 & $21.3 \%$ \\
To ask for help from family & 360 & $66.5 \%$ \\
To ask for help from friends & 193 & $35.7 \%$ \\
To talk to a teacher & 162 & $29.9 \%$ \\
$\begin{array}{l}\text { To use the services of a } \\
\text { psychologist / psychotherapist }\end{array}$ & 211 & $39 \%$ \\
To inform the Police / Justice & 299 & $55.3 \%$ \\
To take revenge & 15 & $2.8 \%$ \\
$\begin{array}{l}\text { To respond with the same } \\
\text { methods to the aggressor }\end{array}$ & 12 & $2.2 \%$ \\
To do nothing & 14 & $2.6 \%$ \\
To block the aggressor online & 256 & $47.3 \%$ \\
$\begin{array}{l}\text { Not to answer challenges from } \\
\text { aggressors }\end{array}$ & 260 & $48.1 \%$ \\
To inform the Police & 2 & $0.4 \%$ \\
\hline
\end{tabular}

For the item "If you inadvertently witness a cyberbullying situation how do you think you would behave" participants provided the following answers presented in Table 5.
Table 5. Results on how respondents would act if they witnessed cyberbullying

\begin{tabular}{lll}
\hline Answer variants & $\begin{array}{l}\text { Nr. of } \\
\text { people }\end{array}$ & $\%$ \\
\hline $\begin{array}{l}\text { I would ignore the situation; it has nothing to do } \\
\text { with me }\end{array}$ & 71 & $13.1 \%$ \\
$\begin{array}{l}\text { I would take an attitude in favor of the victim } \\
\text { I would be happy if the victim is an unbearable }\end{array}$ & 325 & $60.1 \%$ \\
person & & $2 \%$ \\
$\begin{array}{l}\text { I would clearly delimit myself from that } \\
\text { situation, incriminating the aggressor's behavior }\end{array}$ & 50 & $9.2 \%$ \\
$\begin{array}{l}\text { I would pass everything in silence for fear of } \\
\text { becoming a target of cyberbullying }\end{array}$ & 2323 & $\%$ \\
$\begin{array}{l}\text { I would tell the family the situation, asking them } \\
\text { for advice on how to proceed }\end{array}$ & 203 & $37.5 \%$ \\
$\begin{array}{l}\text { I would tell other people in order to find a better } \\
\text { solution with them }\end{array}$ & 224 & $41.4 \%$ \\
$\begin{array}{l}\text { I would beat / immobilize the aggressor } \\
\text { I would talk to the victim and the aggressor }\end{array}$ & 2 & $0.4 \%$ \\
I don't know & 2 & $0.4 \%$ \\
Other & 8 & $1.5 \%$ \\
\hline
\end{tabular}

As can be seen in Table 5, a large number of respondents (325 and $60.1 \%$, respectively) state that they would take an attitude in favor of the victim. Also, some of the respondents would tell the family (203 people, respectively $37.5 \%$ ) or other people in order to find with them the best possible solution (224, respectively $41.4 \%$ ).

\section{Discussions and conclusions}

The Covid 19 pandemic brought a series of changes in daily life. Unlimited internet access, coupled with the natural desire to overcome physical distances by connecting with others has provided an environment conducive to those with aggressive tendencies to engage in acts of cyberbullying. Studies are still insufficient on this topic and seem to highlight an expected increase in the rate of cybercrime (Jain et al., 2020). At the same time, there are studies based on the analysis of online search for data on cyberbullying which finds that during the period when schools physically closed their doors and transferred the educational act to the online environment, the incidence of cyberbullying data searches decreased by using search engines. Search, and the physical reopening of schools, indicates an increase in these searches. (Bacher-Hicks et al. 2021). Therefore, physical interactions seem to stimulate not only bullying behaviors, but also cyberbullying, and as people who use the Internet are better informed about this phenomenon, public authorities seek to develop 
effective programs and tools to prevent and combat this phenomenon. Just as much, some aggressors refine their methods, choose their victims carefully and manage to carry out their plans.

The opinion of the participants who took part in this research, based on the information they each have, is that the phenomenon of cyberbullying is slightly increasing, that there are many intervention strategies through which the phenomenon of cyberbullying even if it cannot be stopped can be diminished by the contribution of each us who at some point may be involved in a cyberbullying situation. For most respondents, the family remains a relevant court in providing support and protection for cases of cyberbullying. In our opinion, there are still many steps to be taken to reduce the impact of this phenomenon, and this can only be achieved through adequate cooperation of public and private authorities to regulate as much as possible the phenomenon of cyberbullying, as well as to advance effective cyberbullying programs, preventing and combating this phenomenon.

\section{Authors note:}

Cristina Ispas is a Ph.D. University Lecturer at the Faculty of Psychology and Sciences of Education, in Educational Sciences Department (Babeş-Bolyai University, Cluj Napoca, Romania). Fields of interest in research: Student Class Management, Pedagogy for Primary and Preschool Education, Teaching Career Management, Inclusive Education.

Ana-Maria Eugenia Ispas is an associate teacher at the Faculty of Psychology and Educational Sciences, Department of Psychology (Babeș Bolyai University, Cluj Napoca, Romania). Areas of interest in research: Fundamentals of psychology, Psychology of education.

\section{References}

Austin, S., \& Joseph, S. (1996). Assessment of bully/victim problems in 8- to 11-year-olds. British Journal of Educational Psy-chology, 66, 447-456. DOI: 10.1111/j.2044-8279.1996.tb01211.x

Bacher-Hicks, A., Goodman, J., Greif Green J., Holt, M.K., (2021). The COVID-19 Pandemic Disrupted Both School Bullying and Cyberbullying, EdWorkingPaper No. 21436, https://doi.org/10.26300/7jy7-x816

Bonil-Nissim, M., \& Sasson, H. (2018). Bullying victimization and poor relationships with parents as risk factors of problematic internet use in adolescence. Computers in Human Behavior, 88, 176-183, DOI: 10.1016/j.chb.2018.05.041

Calvete, E., Orue, I., Estévez, A., Villardón, L., \& Padilla, P. (2010). Cyberbullying in adolescents: Modalities and aggressors' profile. Computers in Human Behavior, 26(5),

1128-1135.

https://doi.org/10.1016/j.chb.2010.03.017

Cortés-Pascual, A., Cano-Escorianza, J., Elboj-Saso, C., Iñiguez-Berrozpe, T. (2020). Positive relationships for the prevention of bullying and cyberbullying: a study in Aragón (Spain), International Journal of Adolescence and

Youth, 25:1, 182-

199, DOI: 10.1080/02673843.2019.1602064

Espelage, D.L., \& Swearer, S.M. (2003). Research on school bullying and victimization: What have we learned and where dowe go from here? School Psychology Review, 32, 365-383

Hinduja, S., \& Patchin, J. W. (2010). Bullying, Cyberbullying, and Suicide, Archives of Suicide Research, 14:3, 206-221, DOI: 10.1080/13811118.2010.494133

Hinduja, S., \& Patchin, J. W. (2014). Cyberbullying: Identification, Prevention, \& Response, Cyberbullying Research Center, https://cyberbullying.org/Cyberbullying-IdentificationPrevention-Response.pdf

Hinduja, S. \& Patchin, J. W. (2020). Cyberbullying Identification, Prevention, and Response. Cyberbullying Research Center, https://cyberbullying.org/Cyberbullying-IdentificationPrevention-Response-2020.pdf

Hinduja, S. \& Patchin, J. W. (2021). Cyberbullying Identification, Prevention, and Response. Cyberbullying Research Center, https://cyberbullying.org/Cyberbullying-IdentificationPrevention-Response-2021.pdf

Ibáñez-Cubillas, P., Díaz-Martín, C., \& Pérez-Torregrosa, A. B. (2017). Social networks and childhood. New agents of socialization. Social and Behavioral Sciences, 237, 64-69, DOI: 10.1016/j.sbspro.2017.02.026

Jain, O., Gupta, M., Satam, S., Panda, S., (2020). Has the covid-19 pandemic affected the susceptibility to cyberbullying in India? Computers in Human Behavior Reports Volume 2, DOI: 10.1016/j.chbr.2020.100029

Katzer, C., Fetchenhauer, D., Belschak, F., (2009) Cyberbullying: Who Are the Victims? A Comparison of Victimization in Internet Chatrooms and Victimization, School. Journal of Media Psychology; Vol. 21(1):25-36. https://doi.org/10.1027/1864-1105.21.1.25

Kowalski, R. M., Giumetti, G. W., Schroeder, A. N., Lattanner, M. R. (2014). Bullying in the digital age: a critical review and meta-analysis of cyberbullying research among youth. Psychological Bulletin, 140(4), 1073-1137. https://doi.org/10.1037/a0035618 
Kowalski, R. M., Limber, S. P., \& Agatston, P. W. (2008). Cyber bullying: Bullying in the digital age. Blackwell Publishing. https://doi.org/10.1002/9780470694176

Kowalski, R. M., Limber, S. P., McCord A. (2019). A developmental approach to cyberbullying: Prevalence and protective factors. Aggression and Violent Behavior 45, 20-32. https://doi.org/10.1016/j.avb.2018.02.009

Palfrey, J., Gasser, U. (2008). Born digital: Understanding the first generation of digital natives. New York, NY: Basic Books.

Patchin, J.W., \& Hinduja, S. (2006). Bullies Move Beyond the Schoolyard: A Preliminary Look at Cyberbullying. Youth Violence and Juvenile Justice, 4(2),

148 -

169. https://doi.org/10.1177/1541204006286288

Smith, P. K., Mahdavi, J., Carvalho, M., Fisher, S., Russell, S., \& Tippett, N. (2008). Cyberbullying: Its Nature and Impact, Secondary School Pupils. Journal of Child Psychology and Psychiatry, 49, 376-385. https://doi.org/10.1111/j.1469-7610.2007.01846.x

Sonone, S.S., Sankhla M.S., Kumar, R. (2020). Cyber Bullying. Chapter 1 in Elshenraki, H.N. (Editor), (2020). Combating the Exploitation of Children in Cyberspace: Emerging Research and Opportunities, Publisher: IGI Global, Hershey, USA. DOI: 10.4018/978-1-7998-23605.ch001

Suler, J. (2004). The online disinhibition effect. Cyberpsychology \& Behavior 7 (3): 321-326. https://doi.org/10.1089/1094931041291295.
Tanrikulu, T., Kinay, H., Aricak, O. T. (2015). Sensibility development program against cyberbullying. New Media $\begin{array}{lllll}\& & \text { Society } & 17 & \text { (5): } & 708-19 .\end{array}$ DOI:10.1177/1461444813511923

Ybarra, M. L., Mitchell, K. J. (2007). Prevalence and frequency of Internet harassment instigation: Implications for adolescent health. Journal of Adolescent Health 41 (2):189-95. doi: 10.1016/j.jadohealth.2007.03.005.

Veenstra, R., Lindenberg, S., Oldehinkel, A. J., De Winter, A. F., Verhulst, F. C., \& Ormel, J. (2005). Bullying and Victimization in Elementary Schools: A Comparison of Bullies, Victims, Bully/Victims, and Uninvolved Preadolescents. Developmental Psychology, 41(4), 672682. https://doi.org/10.1037/0012-1649.41.4.672

Willard, N. E. (2007). Cyberbullying and cyberthreats: Responding to the challenge of online social aggression, threats, and distress. Champaign, IL, Research Press.

https://www.unicef.org/romania/ro/pove\%C8\%99ti/cyberb ullying-ce-este-\%C8\%99i-cum-\%C3\%AEi-punemсар\% $\% 4 \% 83 \mathrm{t}$

https://www.lexico.com/en/definition/cyberbullying https://www.oxfordlearnersdictionaries.com/definition/eng lish/cyberbullying

https://dictionary.cambridge.org/dictionary/english/cyberb ullying

https://www.dictionary.com/browse/cyberbullying 